\title{
The influence of prostaglandins and vasoactive amines on the intestinal phase of experimental trichinellosis
}

\author{
in $\mathrm{CBA}$ mice and $\mathrm{W}$ istar rats
}

\author{
par E. DUTOIT, G. TRONCHIN, A. VERNES et J. BIGUET \\ Unité 42 de l'I.N.S.E.R.M. et Laboratoire de Parasitologie de l'Université de Lille II, \\ Domaine du C.E.R.T.I.A., \\ 369, rue Jules-Guesde, 59650 Flers-bourg, Villeneuve-d'Ascq.
}

\section{Summary.}

The intestinal phase of experimental trichinellosis in CBA mice and Wistar rats is modified by the intraduodenal injection of prostaglandin (PG) $E_{1}$ and, to a greater extent by PG $E_{2}$. The resulting changes are dose-dependent and are a function of the point of the infectious cycle at which the injection is performed. Three dose-related phenomena are thus observable : a delay, an acceleration of the process of expulsion of adult worms or no effect, the latter arising if the prostaglandins are injected later in the cycle. Under the same conditions, no significant effects are exerted by PG A, B or F, by histamine or by serotonin.

\section{Résumé.}

L'influence des prostaglandines et des amines vasoactives sur la phase intestinale de la trichinose expérimentale chez la souris CBA et le rat Wistar.

La phase intestinale de la trichinose expérimentale chez les souris CBA et les rats Wistars est modifiée par l'injection intraduodénale de prostaglandine (PG) $\mathrm{E}_{1}$ et, dans une plus large mesure, de PG $E_{2}$. Les changements qui en résultent dépendent de la dose et sont fonction du moment du cycle infectieux auquel l'injection est pratiquée. Trois phénomènes en relation avec la dose sont ainsi observables: soit un retard, soit une accélération dans le processus d'expulsion des vers adultes, ou encore aucun effet; ce dernier survenant dans le cas où les prostaglandines sont injectées tardivement dans le cours du cycle. Dans les mêmes conditions, aucun effet significatif n'est observé par les PG A, B ou F, ni par l'histamine ou la sérotonine.

Accepté le 29 mai 1979.

Annales de Parasitologie humaine et comparée (Paris), t. $54, \mathrm{n}^{\circ} 4$. 


\section{Introduction}

Prostaglandins (PG), a special family of unsaturated hydroxylated fatty acids, are found in most tissues and body fluids. They are modulators of various types of hormonal actions, but their exact physiological role has not yet been elucidated.

Nevertheless, two publications dealing with experimental nematode parasitosis suggest that PG intervenes in intestinal parasite-host adaptation phenomena. The injection of certain PG, especially PG $\mathrm{E}_{1}$ and PG $\mathrm{E}_{2}$ (250 $\mathrm{\mu g}$ of a chloroform solution) into the duodenum of Wistar rats infested with Nippostrongylus brasiliensis accelerates the expulsion of adult worms in the small intestine. Under the same conditions, biogenic amines, e.g. histamine and 5-hydroxytryptamine, have no effect (Kelly, Dineen, Goodrich and Smith, 1974). PG $E_{2}$ apparently acts differently in trichinellosis in mice, since twice-daily injections at a dose of $150 \mu \mathrm{g} \cdot \mathrm{kg}^{-1} .24 \mathrm{~h}^{-1}$ between days 3 and 30 after injection prolongs survival of adults in the gut (Karmanska and Michalska, 1976).

The aim of the present work was to determine if this difference depended on the parasite model considered or on the host animal, and not on the modalities of introducing the prostaglandins into the host. Using CBA mice and Wistar rats, we studied the action of $P G E_{2}$ on trichinellosis and also examined the effects of two vasoactive amino acids, histamine and serotonin.

\section{Materials and methods}

\section{Protocol.}

Pathogen free CBA mice $(20 \mathrm{~g})$ and Wistar rats $(200 \mathrm{~g})$ were used in this study. Infectious larvae of Trichinella spiralis were obtained from the muscle tissues of CBA mice infested for at least 30 days using the HCl-pepsin digestion technique described by Larsh and Kent (1949). Experimental infestation was obtained by introduction of 200 larvae via oesophageal intubation. The various products tested were injected intraduodenally after ether anesthesia and laparotomy. After sacrifice male and female adult worms in the small intestine were counted using the method of Baermann (1917). Each control and experimental group involved 10 animals. The Student-Fischer test was utilized to calculate the value of $t$.

\section{Determination of infestation kinetics.}

After infesting $25 \mathrm{CBA}$ mice as described above, sacrifice and counting of adult male and female worms was performed on days $3,5,7,10,11,13$ and 15 . This preliminary experiment was performed in order to determine the moment at which experimental animals had to be sacrificed. 
Phosphate buffer and dimethylsulfoxide (DMSO) (table I, group 1).

It was necessary to determine if these solvents had an effect on the number of adult worms collected on day 7. Two groups of 10 animals each were infested. One group then received an intraduodenal injection of $0.1 \mathrm{ml}$ of phosphate buffer and the other one received the same volume of DMSO. The number of adult worms was determined and $t$ was calculated.

Table I. - Intraduodenal injection of $50 \mathrm{~g}$ of test product in CBA mice.

\begin{tabular}{|c|c|c|}
\hline & $\begin{array}{l}\text { Worms per mouse } \\
\text { (mean } \pm \text { S.E.M.) }\end{array}$ & $t$ \\
\hline \multicolumn{3}{|l|}{ GROUP 1} \\
\hline Controls .......... & $50.6 \pm 0.80$ & \\
\hline 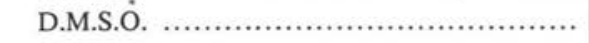 & $50.9 \pm 0.50$ & 0.15 N.S. \\
\hline Phosphate Buffer ......................., & $46.7 \pm 0.29$ & 2.08 N.S. \\
\hline \multicolumn{3}{|l|}{ GROUP 2} \\
\hline 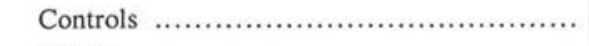 & $55.4 \pm 2$ & \\
\hline 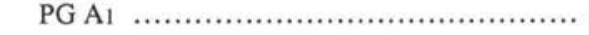 & $57.9 \pm 5$ & 0.45 N.S. \\
\hline 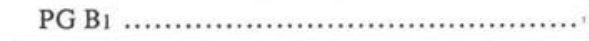 & $62.3 \pm 6.3$ & 1.04 N.S. \\
\hline \multicolumn{3}{|l|}{ GROUP 3} \\
\hline Controls ................ & $71.6 \pm 2$ & \\
\hline 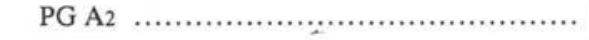 & $64.5 \pm 4.3$ & 1.49 N.S. \\
\hline 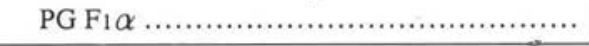 & $75 \pm 17$ & 0.19 N.S. \\
\hline \multicolumn{3}{|l|}{ GROUP 4} \\
\hline Controls ... & $73.6 \pm 2$ & \\
\hline PG E1 ........ & $118.9 \pm 5.9$ & $7.27^{*}$ \\
\hline PG E2 & $131.7 \pm 3.9$ & $13.25^{* *}$ \\
\hline \multicolumn{3}{|l|}{ GROUP 5} \\
\hline Controls ... & $80.8 \pm 11.2$ & \\
\hline 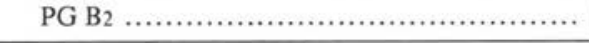 & $83.1 \pm 5.3$ & 0.18 N.S. \\
\hline \multicolumn{3}{|l|}{ GROUP 6} \\
\hline Controls ...... & $48 \pm 2$ & \\
\hline 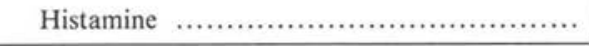 & $39.2 \pm 1.79$ & 3.27 N.S. \\
\hline \multicolumn{3}{|l|}{ GROUP 7} \\
\hline 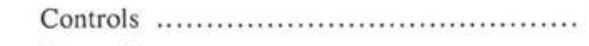 & $46.6 \pm 2$ & \\
\hline 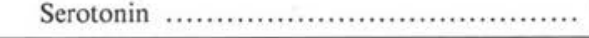 & $43.7 \pm 0.69$ & 1.36 N.S. \\
\hline
\end{tabular}

$t$ : Student-Fischer test

N.S. : non-significant

$*$ : significant difference $p \leqslant 0.05$

** : significant difference $p \leqslant 0.01$ 
Vasoactive amines (table I, groups 6 and 7).

Two groups of $10 \mathrm{CBA}$ mice were used. At day 3 after infestation, one group received $8 \mathrm{mg}$ of histamine. $\mathrm{HCl}$ intraduodenally and the other group similarly received $4 \mathrm{mg}$ of serotonin. In both cases, the solvent was $0.1 \mathrm{ml}$ of phosphate buffer, $\mathrm{pH}$ 7.2. Controls received the same volume of buffer intraduodenally.

\section{Prostaglandins.}

The following prostaglandins were generously furnished by Upjohn Laboratories: $A_{1}, A_{2}, B_{1}, B_{2}, E_{1}, E_{2}$ and $F_{1} \alpha$. Each product was dissolved in $0.1 \mathrm{ml}$ of DMSO immediately before injection. Controls received the same volume of DMSO intraduodenally (DMSO was chosen over chloroform in view of the toxicity of the latter in mice).

\section{In $C B A$ mice.}

Initially, we compared the activities of $50 \mu \mathrm{g}$ of each prostaglandin injected intraduodenally 3 days after infestation. Sacrifice was performed 4 days later (day 7) and the numbers of adult worms were determined (table I, groups 2-5). Based on the results of this series of experiements, we then repeated this protocol using $25 \mu \mathrm{g}$ of PG $\mathrm{E}_{2}$ (table II, group A). Next, we intraduodenally injected $25 \mu \mathrm{g}$ of PG $\mathrm{E}_{2}$ at the time when self-cure occurs, i.e. day 6 after infestation, counting the number of adult worms on day 9 (table II, group B). Finally, we injected $250 \mu \mathrm{g}$ of PG $\mathrm{E}_{2}$ into each of 10 mice.

Table II: - Intraduodenal injection of $P G E_{2}$ in $C B A$ mice.

\begin{tabular}{|c|c|c|}
\hline & $\begin{array}{l}\text { Worms per mouse } \\
\text { (mean } \pm \text { S.E.M.) }\end{array}$ & $t$ \\
\hline GROUP A & & \\
\hline 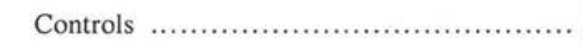 & $84.2 \pm 5.1$ & \\
\hline 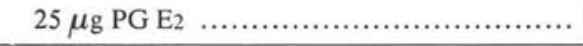 & $116.2 \pm 5.3$ & $4.33^{* *}$ \\
\hline \multicolumn{3}{|l|}{ GROUP B } \\
\hline 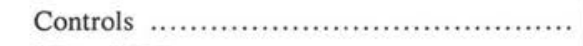 & $70.1 \pm 19.3$ & \\
\hline 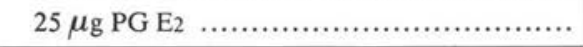 & $60.8 \pm 4.5$ & 0.46 N.S \\
\hline \multicolumn{3}{|l|}{ GROUP C } \\
\hline 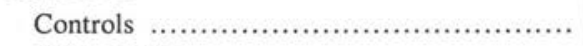 & $73.6 \pm 2$ & \\
\hline 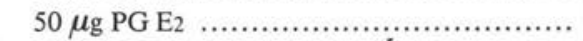 & $131.7 \pm 3.9$ & $13.25^{* *}$ \\
\hline
\end{tabular}

$t:$ Student-Fischer test

N.S. : non-significant

* : significant difference $p \leqslant 0.05$

** : significant difference $p \leqslant 0.01$ 
In Wistar rats.

We tested only prostaglandins $B_{1}$ and $E_{2}$ in this species. Three days after infestation with 200 larvae, we intraduodenally injected $200 \mathrm{~g}$ rats with $250 \mu \mathrm{g}$ of each prostaglandin, a ten-fold greater dose than mice weighing $20 \mathrm{~g}$. The results are shown in table III, group 1. Under the same experimental conditions, we then injected $500 \mu \mathrm{g}$ of PG $\mathrm{E}_{2}$ (table III, group 2). Simultaneously with the determination of the number of adults recovered on day 7 , we also desired to test the effect of this dose of PG on the fertility of female trichinella worms. This experiment lasted 24 hours and was performed in vitro in medium 199, according to the protocol of Jacqueline, Vernes and Biguet (1978) with groups of 30 control females and 50 PG $\mathrm{E}_{2}$-treated females.

\section{Statistical analyses.}

The Student-Fischer test was used.

\section{Results}

Kineties of intestinal infestation of controls (fig. 1).

The maximum number of adult worms was scored on day 7 post-infestation, the point at which self-cure begins. A drastic decrease in the number of adults was

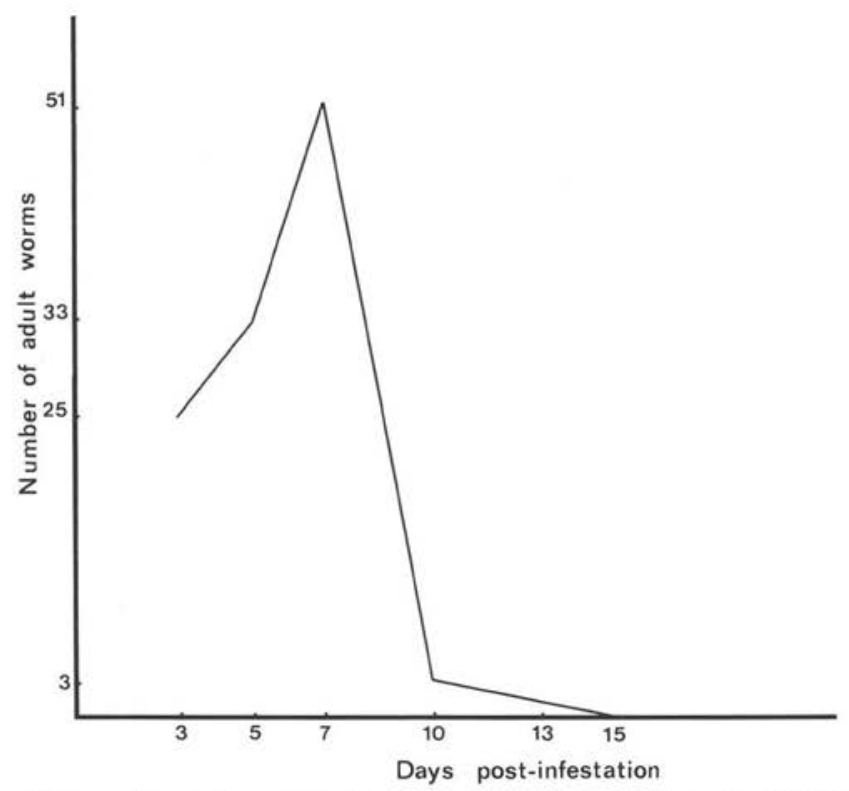

Fig. 1. Mean evolution of number of adult worms in mice infested with $200 \mathrm{~T}$. spiralis larva on day 0 
observed on day 10 with complete elimination at day 15 . Adult worms were henceforth scored on day 7.

Effect of phosphate buffer and dimethylsulfoxide (DMSO) on infestation (table I, group 1).

The absence of significant differences among the groups demonstrates that phosphate buffer and DMSO had no effect on the expulsion of Trichinella spiralis from the gut.

Infestation of controls during various experimental series (table $I$, groups 2-7; table II, groups $A-C$; table III, groups 1 and 2).

The experiments were spread over three months as a result of the variable infectivity of the strain. Each group of injected animals was accompanied by a corresponding control group of 10 animals. The population of adult worms determined in controls on day 7 varied significantly, since 46.6 adults were scored in serotonin controls and 80.8 in PG $\mathrm{B}_{2}$ controls. The exact reasons for these differences in infectivity are presently unknown.

Table III. - Experiments with Wistar rats.

\begin{tabular}{|c|c|c|}
\hline & $\begin{array}{l}\text { Worms per mouse } \\
\text { (mean } \pm \text { S.E.M.) }\end{array}$ & $t$ \\
\hline \multicolumn{3}{|l|}{ GROUP 1} \\
\hline 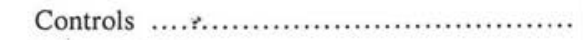 & $85 \pm 2$ & \\
\hline 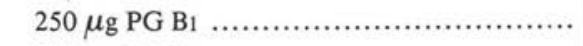 & $70 \pm 10$ & 1.39 N.S. \\
\hline 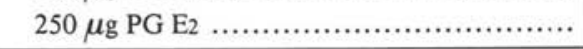 & $118 \pm 4.5$ & $6.47^{*}$ \\
\hline \multicolumn{3}{|l|}{ GROUP 2} \\
\hline 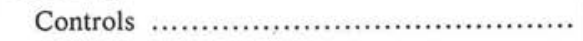 & $103 \pm 4.4$ & \\
\hline 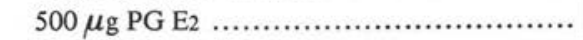 & $54 \pm 3.8$ & $7.86^{* *}$ \\
\hline
\end{tabular}

$t:$ Student-Fischer test

N.S. : non-significant

*: significant difference $p \leqslant 0.05$

** : significant difference $p \leqslant 0.01$

Effects of vasoactive amines (table $I$, groups 6 and 7).

Histamine and serotonin had no effect, compared with their respective phosphate buffer controls. 


\section{Effects of prostaglandins.}

In $C B A$ mice.

The following conclusions could be reached after comparing each group of treated mice with controls (table I, groups 2-5).

There was no apparent difference between groups $A_{1}$ and $B_{1}$ and their controls, between groups $A_{2}$ and $F_{1} \alpha$ and their controls and between the PG $B_{2}$ group and its control.

In the group of PG $\mathrm{E}_{1}$-treated animals, however, 118.9 adult worms were scored on day 7 and 131.7 were counted in PG $\mathrm{E}_{2}$ animals, while controls contained only 73.6 adults. This difference is statistically significant, the number of worms in the PG $\mathrm{E}_{1}$ group is increasing by $61.5 \%$ and that in the PG $\mathrm{E}_{2}$ group by $79 \%$.

These two prostaglandins thus favor the survival of adult $T$. spiralis in the gut. In addition, $\mathrm{PG} \mathrm{E}_{2}$ delays the process of expulsion of adult worms (table II, group A).

When $P G E_{2}$ was injected during the period of self-cure, there was no effect on the number of adults scored at day 9 post-infestation (table II, group B).

Finally, a PG $E_{2}$ dose of $250 \mu \mathrm{g}$ led to the death of the animals within 1 to 3 hours, attesting to the toxicity of this dose in CBA mice.

\section{In Wistar rats.}

There was no significant difference between the PG $B_{1}$ group and its control, but there exists a statistically valid difference between the PG $E_{2}$ group and the same control (table III, group 1).

Following the administration of $500 \mu \mathrm{g}$ of $\mathrm{PG} \mathrm{E}_{2}$, the number of worms scored was 54, while the corresponding figure in controls was 103 (table III, group 2). This difference is statistically significant $(p<0.01)$.

Concerning the fertility of female worms harvested on day 7 , we found that controls laid an average of 33 larvae, while females of group PG $\mathrm{E}_{2}$ gave rise to only 2. These results are significant and are consistent with those of Kelly et al. (1974) obtained with $N$. brasiliensis.

\section{Discussion}

With the experimental model used in the present experiments, we found that single doses of $8 \mathrm{mg}$ of histamine or of $4 \mathrm{mg}$ of serotonin had no effect on the expulsion of adult Trichinella worms. This conclusion had been reached previously by Kelly et al. (1974) who administered single doses of these amines to rats infested with $N$. brasiliensis.

According to Keller and Ogilvie (1972), $15 \mathrm{mg}$ of histamine per $\mathrm{kg}$ administered over several days also had no effect in the same model. Thus, the auto-release mechanism observed in trichinellosis or nippostronglylosis would be different from the immediate hypersensitivity phenomenon proposed by Stewart (1955) to explain 
the self-cure of sheep infested with various Trichostrongylidae, particularly Haemonchus contortus. Following field studies of this same parasitosis by Allonby and Urquhart (1973), arguments were advanced favoring a non-immunological origin of self-cure.

The variance analysis of the mean values of the various series of prostaglandins treated animals has shown that they significantly differ between them $(0,001<p$ $<0,01)$. Among the seven prostaglandins tested in the present experiment, only $\mathrm{E}_{1}$ and $\mathrm{E}_{2}$ and particularly the latter, were capable of effectively interfering with the natural progression of trichinellosis in experimental animals.

When 25 or $50 \mu \mathrm{g}$ of PG $\mathrm{E}_{2}$ were injected into CBA mice on day 3 following infestation, the number of adult worms scored in the gut on day 7 was much greater than that observed in non-treated, infested controls. These results confirm those of Karmanska and Michalska (1976) who studied only PG $E_{2}$, but the present results furnish important data on the modalities of PG effectiveness. In our experiments, this effectiveness was indeed demonstrated by the introduction of a single dose of PG $E_{2}$ in situ, while the Polish workers employed daily intraperitoneal injections of $150 \mu \mathrm{g} / \mathrm{kg}$ for almost one month. This protocol, or any other characterized by repeated injections of $P G E_{2}$, should have shown itself indispensible for delaying the elimination of adult trichinella worms.

At the time of self-cure, when immunological mechanisms are already in place, PG $E_{2}$ no longer has an effect. This was observed in mice when $25 \mu \mathrm{g}$ of PG $\mathrm{E}_{2}$ were injected on day 6 and adult worms were scored on day 9.

In order to eliminate adult worms by day 7 in Wistar rats, a PG $E_{2}$ dose of $250 \mathrm{\mu g}$ is necessary. This dose is sufficient to accelerate the elimination of $\mathrm{N}$. brasiliensis (Kelly et al., 1974) but acceleration of $T$. spiralis is obtained only with $500 \mu \mathrm{g}$ of PG $\mathrm{E}_{2}$.

The mechanism of action of $P G E_{1}$ and $E_{2}$ remain to be understood. Following the administration of an appropriate dose of $\mathrm{PG}_{2}$ to mice or rats, adult worms are retained. We may explain this by invoking the hypothesis that PG inhibits delayed hypersensitivity and/or immediate hypersensitivity (Perrin, 1974); the important role of these processes in trichinellosis self-cure is well known.

The accelerated expulsion of worms obtained with $500 \mu \mathrm{g}$ of PG $\mathrm{E}_{2}$ in Wistar rats could be due to different effects :

1) PG E may directly affect metabolism of the parasite. However, expulsion is preceded by structural and metabolic damage to worms (Ogilvie and Hockley, 1969 ; Edwards et al., 1971). Jones and Ogilvie (1971) have shown that worm damage is mediated by antibodies and they have suggested that antibodies cause worm damage directly. In this event, antibodies may provide the specific immunological trigger for the action of PG E. The suggestion that PG E plays a direct role in worm damage is supported by the observation that PG E, at physiological concentration, causes metabolic damage to $N$. brasiliensis adult worms cultured in vitro (Richards et al., 1975). 
2) Elevated levels of PG E act indirectly by affecting gastrointestinal function which alters the microenvironnement at the site of infection (Kelly and Dineen, 1976). During his studies, Castro (1976) observed that parasites in the gut led not only to inflammatory phenomena, but also to a change in the intestinal microenvironnement, which could explain a change in intestinal mobility with a resulting diarrhea. This effect was also observed by Robert (1977) in human volunteers and in dogs following the administration of high doses of PG $\mathrm{E}_{2}$.

For each animal species, there is an obvious relationship between the time of PG injection, the dose injected and the effect observed. We thus believe it inappropriate to compare dose-effect phenomena in two species as different as mice and rats.

There remains the behavioral difference between $N$. brasiliensis (Kelly et al., 1974) and $T$. spiralis to explain. The former may be more sensitive to PG $\mathrm{E}_{2}$ and perhaps may more easily experience the effects of mucosal changes, since the majority of adult worms are enmeshed in intestinal villosities and apparently do not penetrate the lamina propria (Barth, Jarret and Urquhart, 1966).

Furthermore, since these worms have neither teeth nor a buccal capsule, it is probable that they are not very strongly attached to the mucosa or at any rate are much less so than the trichinella worm, which penetrates relatively deeply.

The expulsion of adult $T$. spiralis is obtained only with high doses of PG $\mathrm{E}_{2}$, which may also reflect a lower PG sensitivity than $N$. brasiliensis.

Recently, Larsh et al. (1975) have reported that phospholipase activity is elevated in the gastro-intestinal tract during expulsion of several parasites in various host species. We also know that phospholipases are crucial enzymes in the release of fatty acid precursors of PG. In summary, interrelationships among physiology, immunology and pathology play a fundamental role in the parasite-intestinal microenvironnement complex. Serum or tissue factors, such as prostaglandins, may specifically modulate the host response to parasite aggression.

\section{ACKNOWLEDGEMENTS}

This research was supported by INSERM grant No CRL 755.099. We thank the Upjohn Corporation (Kalamazoo, Michigan, U.S.A.) for kindly supplying the prostaglandins used in this work.

\section{References}

Allonby E.W., Urquhart G. M. (1973): Self-cure of Haemonchus contortus infection under field condition. Parasitology, 66, 43-53.

Baermann G. (1917) : Eine einfache methode zur Auffindung von Ankylostomum (Nematoden) Larven in Erdproben. Geneesk Tijdschr Nederland Indie, 57, 131-137.

Barth E. E. E., Jarret W. F. H., Urquhart G. M. (1966): Studies on the mechanism of the self-cure reaction in rats infected with Nippostrongylus brasiliensis. Immunology, 10, 459-464.

Castro G. A. (1976) : Spatial and temporal integration of host responses to intestinal stages of Trichinella spiralis: retro and prospective views. Biochemistry of parasites and host-parasite relationships, H. Van den Bossche Ed., 343-358. 
Edwards A. J., Burt J.S., Ogilvie B.M. (1971): The effect of immunity upon some enzymes of the parasitic nematode, Nippostrongylus brasiliensis. Parasitology, 62, 339-347.

Jacqueline E., Vernes A., Biguet J. (1978) : Trichinella spiralis: Facteurs immunitaires inhibiteurs de la production de larves. I. Mise en évidence in vivo et in vitro chez la souris. Exp. parasitol., $45,34-41$.

Jones V.E., Ogilvie B. M. (1971) : Protective immunity to Nippostrongylus brasiliensis: the sequence of events which expels worms from the rat intestine. Immunology, London, 20, 549-561.

Karmanska K., Michalska Z. (August 1976): The influence of prostaglandin $\mathrm{E}_{2}\left(\mathrm{PG} \mathrm{E}_{2}\right)$ on the course of experimental trichinellosis in mice. Fourth International Conference on Trichinellosis, Poznan.

Keller R., Ogilvie B.M. (1972): The effects of drugs in worm expulsion in the Nippostrongylus brasiliensis infected rat. A discussion of the interpretation of drug action. Parasitology, Cambridge, $64,217-228$.

Kelly J.D., Dineen J.K., Goodrich B.S., Smith I.D. (1974) : Expulsion of Nippostrongylus brasiliensis from the intestine of rats. Int. Arch. Allergy Appl. Immunol., 47, 458-465.

Kelly J.D., Dineen J.K. (1976) : Prostaglandins in the gastro-intestinal tract: evidence for a role in worm expulsion. Aust. Vet. J., 52, 391.

Larsh J.E. Jr, Kent D.E. (1949) : The effect of alcohol on natural and acquired immunity of mice to infection with Trichinella spiralis. J. Parasitol., 35, 45-53.

Larsh J. E., Ottolenghi A., Weatherly N.F. (1975) : Trichinella spiralis : phospholipase in sensitized mice after challenge. Exp. Parasitol., 37, 233-238.

Ogilvie B. M., Hockley D. J. (1969) : Effects of immunity on Nippostrongylus brasiliensis adult worms: reversible and irreversible changes in infectivity, reproduction and morphology. $J$. Parasitol., 54, 1073-1084.

Perrin L.-F. (1974): Les prostaglandines et la réponse immunitaire. Rev. Franç. Allergol., 14, 213-216.

Richards A. J., Kelly J. D., Dineen J. K., Bryant C. (1975) : Carbohydrate metabolism in Nippostrongylus brasiliensis. Proceeding of Annual General Meeting Austria Society for Parasitology, p. 19.

Robert A. (1977): Prostaglandins and the digestive system. Reprinted from: the prostaglandins, vol. 3. Peter W. Ramwell, Publ., New York.

Stewart D. F. (1955): Self-cure in nematode infestations of sheep. Nature, London, 176, 1273-1274. 